\title{
Biophysical Characterization of Palm Oil Mill Effluent from Adapalm, Imo State Nigeria
}

\begin{abstract}
Keywords: Environment; Fungi; Physicochemical; Waste discharge Abstract

This study was designed to investigate the biophysical characteristics of Palm Oil Mill Effluent (POME) produced by ADAPALM oil mill, Imo State, Nigeria. A total of three samples were ascetically collected from the mills. The POME was subjected to standard microbiological analysis and physiochemical studies. The population of Total Heterotrophic Bacteria (THB) ranged from $1.71 \times 104-1.90 \times 104$ (cfu/g), the Total Heterotrophic Fungi (THF) ranged from $4.70 \times 102-7.00$ $\times 102$ (cfu/g). The bacteria isolated from the POME followed the order Staphylococcus sp. (38\%) >Pseudomonas sp. (32\%) > Serratia sp. and Bacillus sp. (15\%), while the fungi isolate from POME include Aspergillus niger, Aspergillu flavu, Penicillium Specie and Mucor species. The physiochemical characteristics showed range of $3.98 \pm 0.03$ to $4.22 \pm$ 0.02 for $\mathrm{pH}$, electrical conductivity from $291 \pm 0.8$ to $312 \pm 1.6 \mu \mathrm{S} / \mathrm{cm}$, temperature from $27.2 \pm 28.8 \pm 0.1$ oC and moisture content from $4.1 \pm$ 0.4 to $6.0 \pm 0.1 \%$ respectively. Although, the POME contains microbial species capable of degrading hydrocarbons in the POME to prevent environmental impacts, the results showed possible non existence of effluent treatment of any form.
\end{abstract}

\section{Introduction}

The palm oil (Elaeis Guineensis) industry in Nigeria is very important and vital for the Nigerian economy, which represents 3\% of the world production in 2010 [1]. Thus increasing its cultivation in many parts of Nigeria especially the Niger Delta. With the economic benefits comes environmental problem associated with effluents from the industry. These effluent products consist of solids materials such as Empty Fruit Bunches (EFB), Palm Pressed Fibers' (PPF), Palm Kernel Shell (PKS), Palm Kernel Cake (PKC) and liquid effluents such as Palm Oil Mill Effluent (POME) [1-5].

Palm oil mill effluent is the voluminous liquid waste that comes from the sterilization and clarification processes in milling oil palm. The raw effluent contains $90-95 \%$ water and includes residual oil, soil particles and suspended solids [6]. About $2.5 \mathrm{t}$ of effluent per tonne of palm oil, or 0.5 tonne of effluent per tonne of fresh fruit is produced by a palm industry. POME is a highly polluting material and it continuous deposition in an area will cause the area to be abandoned and fresh space is located. Several reports have stressed the ecological and pollution hazards associated with this disposal method [7].Thus prompting much research dedicated to the means of alleviating its threat to the environment through assessing its physicochemical and biological properties. These are essential characteristics to be investigated before discharging POME to the recipient environment [8].

Several studies have been conducted on POME from different palm extraction sites [7-11]. While studies in I'm state has been limited. Verla and coworkers studied POME randomly collected at source and from a dump site in Nguru, AbohMbaise, Imo state Nigeria

\section{Environmental Studies}

\author{
Ihenetu SC, Enyoh CE*, Uzoigwe AD, Ubah OG \\ ${ }^{I}$ Department of Chemistry, Imo State University Owerri, Nigeria \\ ${ }^{2}$ Department of Agronomy, Micheal Opara University of Agriculture \\ Umudike, Nigeria \\ ${ }^{3}$ Department of Microbiology, University of Portharcourt, Nigeria \\ *Address for Correspondence \\ Enyoh Christian Ebere, Group Research in Analytical Chemistry, \\ Environment and Climate Change (GRACE\&CC), Department of Chemistry, \\ Imo State University Owerri, Nigeria; E-mail: cenyoh@gmail.com \\ Submission: 27 August, 2018 \\ Accepted: 2 September, 2018 \\ Published: 8 October, 2018 \\ Copyright: (c) 2018 Ihenetu et al. This is an open access article \\ distributed under the Creative Commons Attribution License, which \\ permits unrestricted use, distribution, and reproduction in any medium, \\ provided the original work is properly cited.
}

for physicochemical and microbial properties [4]. Results revealed that POME characteristics were far above Environmental Health and Safety guidelines, which indicates unhealthy environment conditions with potential negative consequences for humans and the ecosystem. There is therefore need for environmental agencies and governments to take appropriate preventive measures to avert potential problems due to indiscriminate dumping of POME [12]. The aim of this study is to characterize POME from Adapalm. As far as it could be established no study has reported on the characteristics of POME from Adaplam. Therefore, this paper reports the physicochemical, biochemical and microbial qualities of POME from Adapalm, Imo state Nigeria.

\section{Materials and Methods}

\section{Site description and sample collection}

The study area is located at Ohaji Egbema Local Government Area of Imo State. The farm was established in 1962 as Ohaji Farm settlement and a size of 4319 hectares of plantation [13]. Geographically, the area lies within coordinates of $5.3138^{\circ} \mathrm{N}, 6.8780$ ${ }^{\circ} \mathrm{E}$.

Three (3) samples of Palm Oil Mill Effluent generated were collected ascetically with sterile $500 \mathrm{ml}$ bottles from different mills in adapalm which were labeled A, B and C and were taken to the Imo state university microbiology laboratory where they were analyzed.

\section{Quality control}

All chemicals used for this work were analytical grade chemicals purchased from Fin. Lab and ChemiScience, Owerri and were used without further purification. All glassware and media used were sterilized by autoclaving at $121^{\circ} \mathrm{C}$ for $15 \mathrm{mins}$ at 15 pounds pressure and air drying in the hot air oven at $160^{\circ} \mathrm{C}$ for $2 \mathrm{hrs}$.

\section{Methods for physical analysis of POME}

Determination of POME temperature: The thermometer was inserted inside the sample and it was allowed to stay for about 5 minutes before taking the temperature reading of the sample. 
Citation: Chukwuemeka IS, Ebere EC, Donald UA, Gerald UO. Biophysical Characterization of Palm Oil Mill Effluent from Adapalm, Imo State Nigeria. J Environ Stud. 2018;4(1): 4.

ISSN: 2471-4879

Table 1: Total bacterial and fungal counts for all the POME samples.

\begin{tabular}{|c|c|c|}
\hline POME Samples & Bacteria count (cfu/g) & Fungi count (cfu/g) \\
\hline Sample A & $1.90 \times 10^{4}$ & $7.00 \times 10^{2}$ \\
\hline Sample B & $1.71 \times 10^{4}$ & $6.20 \times 10^{2}$ \\
\hline Sample C & $1.86 \times 10^{4}$ & $4.70 \times 10^{2}$ \\
\hline
\end{tabular}

Table 2: Bacterial isolates.

\begin{tabular}{|c|c|c|c|}
\hline$S / N$ & Microorganism isolated & No of isolate & $\%$ isolated \\
\hline \multicolumn{4}{|c|}{ Sample A } \\
\hline 1 & Staphylococcus spp. & 16 & 37.2 \\
\hline 2 & Pseudomonas spp. & 14 & 32.5 \\
\hline 3 & Seratia spp. & 5 & 11.6 \\
\hline 4 & Bacillus spp. & 8 & 18.6 \\
\hline \multicolumn{4}{|c|}{ Sample B } \\
\hline 1 & Staphylococcus spp. & 13 & 37.1 \\
\hline 2 & Pseudomonas spp. & 11 & 31.4 \\
\hline 3 & Seratiaspp. & 6 & 17.1 \\
\hline 4 & Bacillus spp. & 5 & 14.3 \\
\hline \multicolumn{4}{|c|}{ Sample C } \\
\hline 1 & Staphylococcus spp. & 14 & 38.9 \\
\hline 2 & Pseudomonas spp. & 12 & 33.3 \\
\hline 3 & Seratiaspp & 6 & 16.6 \\
\hline 4 & Bacillus spp. & 4 & 11.1 \\
\hline \multicolumn{4}{|c|}{ Total Isolate } \\
\hline 1 & Staphylococcus spp. & 43 & 38 \\
\hline 2 & Pseudomonas spp. & 37 & 32 \\
\hline 3 & Seratiaspp. & 17 & 15 \\
\hline 4 & Bacillus spp. & 17 & 15 \\
\hline
\end{tabular}

Determination of electrical conductivity: The electrical conductivity was determined by using the HANNA HI8733 electrical conductivity. The electrical conductivity meter was first calibrated using solution of potassium chloride [14]. $200 \mathrm{ml}$ of the sample was measured into $500 \mathrm{ml}$ beaker and it was allowed to stay for about 30 minutes. The electrode was dipped into the beaker and the reading was obtained from the electrical conductivity screen.

Determination of the $\mathbf{p H}$ : The $\mathrm{pH}$ meter was first standardized in buffer solution of 4,10 and 7. $150 \mathrm{ml}$ of the sample was weighed into $250 \mathrm{ml}$ beaker and was stirred for about 30 minutes and it was allowed to stay for 2 hours. The $\mathrm{pH}$ electrode was dipped into the beaker and it was allowed to stand for about 5 minutes before taking the reading [14-15].

Moisture content: Aliquot of $10 \mathrm{ml}$ of each sample was added into a silica dish. This was immersed in a water bath until the water was completely evaporated. The dried solids in the silica dish was then removed from the water bath and dried at $70{ }^{\circ} \mathrm{C}$ in a vacuum oven for 3 hours and then placed in the desiccators for 10 minutes, for cooling. The content of the dish was weighed and the moisture content calculated as follows [16].

$\%$ moisture content $=\frac{\text { weight of sample after drying }}{\text { weight of sample before drying }} \times \frac{100}{1}$

\section{Microbiological analysis of samples}

Total heterotrophic bacteria count and fungi count: The populations of microorganisms in the samples were enumerated using serial dilution pour plate method. About $0.1 \mathrm{ml}$ of POME sample was serially diluted in sterile distilled/deionized water and aliquots of the dilutions were ascetically plated into the media (Nutrient Agar and Sabouraud Dextrose Agar for bacteria and fungi respectively). The agar plates were incubated at $37^{\circ} \mathrm{C}$ for $24-48$ hours to enumerate the aerobe and facultative bacteria and the fungi culture plates were incubated and inverted at $30{ }^{\circ} \mathrm{C}$ for 3-5 days. After incubation, the colonies that grew on the medium were counted and expressed as colony forming units $(\mathrm{cfu}) / \mathrm{ml}$ of the samples. Microbial colonies were isolated into pure cultures and preserved in slants for further analysis [16].

\section{Identification of isolates}

The samples were identified using their morphological and cultural identification and further subjected to biochemical characterization.

\section{Data analysis}

Analysis of Variance (ANOVA) was used to test significant differences at $5 \%$ level of significance.

\section{Result and Discussion}

\section{Microbiological result}

The microbial population of POME is presented in (Table 1). The total bacteria count ranges from $1.71 \times 10^{4}-1.90 \times 10^{4}(\mathrm{cfu} / \mathrm{g})$. The total fungi count ranges from $4.70 \times 10^{2}-7.00 \times 10^{2}(\mathrm{cfu} / \mathrm{g})$.

From the result obtained from the total bacteria count ranges from $1.71 \times 10^{4}-1.90 \times 10^{4}(\mathrm{cfu} / \mathrm{g})$ (Table 1$)$. The total fungi count ranges from $4.70 \times 10^{2}-7.00 \times 10^{2}(\mathrm{cfu} / \mathrm{g})$. The result showed that all the samples collected from various mills have similar microbial species

\section{Identification of bacterial isolates}

The result in showed that all the samples collected from various mills have similar microbial species (Table 2). The bacteria isolated from the POME include Pseudomonas sp.,Serratia sp, Bacillus sp, and Staphylococcus sp.

The result obtained from shows that all the samples collected from various mills have similar microbial species (Table 2). The bacteria isolated from the POME followed the order Staphylococcus sp. (38\%)

Table 3: Biochemical test of bacteria isolates of POME.

\begin{tabular}{|c|c|c|c|c|c|c|c|c|c|c|c|}
\hline Organism & $\begin{array}{c}\text { Gram } \\
\text { reaction }\end{array}$ & Mor & Oxi & Cat & Cit & Coa & Ure & Ind & Glu & Gal & Lac \\
\hline $\begin{array}{c}\text { Pseudomonas } \\
\text { sp }\end{array}$ & Negative rod & + & + & + & + & - & - & - & A & - & - \\
\hline Serratia sp & Negative rod & + & + & + & + & - & - & - & A/G & A/G & A \\
\hline Bacillus sp & Positive rod & + & + & + & + & - & - & - & A & A/G & A \\
\hline $\begin{array}{c}\text { Staphylococcus } \\
\text { sp }\end{array}$ & $\begin{array}{c}\text { Positive } \\
\text { cocci }\end{array}$ & - & - & + & - & + & - & - & A/G & A/G & A/G \\
\hline
\end{tabular}

Keys: +: Positive; -: Negative Reaction; A: Acid; A/G: Acid and Gas; Oxi: Oxidase; Cat: Catalase; Cit: Citrate; Coa: Coagulase; Ure: Urease; Ind: Indole; Glu: Glucose; Gal: Galactose; Lac: Lactose; Mo: Motility 
Citation: Chukwuemeka IS, Ebere EC, Donald UA, Gerald UO. Biophysical Characterization of Palm Oil Mill Effluent from Adapalm, Imo State Nigeria. J Environ Stud. 2018;4(1): 4

ISSN: $2471-4879$

Table 4: Microscopic morphology and cultural characteristics.

\begin{tabular}{|c|c|c|}
\hline Organisms & Microscopic morphology & Cultural characteristics \\
\hline Aspergillus & \multirow{2}{*}{$\begin{array}{l}\text { Presence of septate hyphae; long and smooth conidiophores, long } \\
\text { unbranded sporangiospores with large, round head. }\end{array}$} & \multirow{2}{*}{$\begin{array}{l}\text { Creamy to brownish-black mycelium with dark spores and often } \\
\text { appears golden on the reverse side. }\end{array}$} \\
\hline Niger & & \\
\hline Aspergillus & \multirow{2}{*}{$\begin{array}{l}\text { Presence of septate hyphae, colourless and rough conidiophores with } \\
\text { swollen vesicles. }\end{array}$} & \multirow{2}{*}{$\begin{array}{l}\text { A greenish-yellow colour with a creamy edge. That appears } \\
\text { golden in the reverse of the septate }\end{array}$} \\
\hline Flavus & & \\
\hline \multirow{2}{*}{ Mucorspecies } & Presence of non septate hyphae with a visible spore and short & \multirow{2}{*}{$\begin{array}{c}\text { A creamy colonies that covers the entire medium and they are } \\
\text { irregular in shape. }\end{array}$} \\
\hline & sporangiosphores. & \\
\hline Penicillium & $\begin{array}{l}\text { Presence of septate and fruity mycelium and branched conidiophores. It } \\
\text { has a red pigment, and the edge is surrounded by }\end{array}$ & A greenish filament is seen which changes to powdery \\
\hline Species & whitish margin & Greenish brown after days and it is yellow on the reverse side. \\
\hline
\end{tabular}

$>$ Pseudomonas sp. (32\%) > Serratia sp/Bacillus sp (15\%) There was abundant occurrence of Staphylococcus sp in all samples compared to all other bacterial isolated. Our results showed variation to results of and $[4,19]$. Eze (19) reported highest occurrence of Pseudomonas aeruginosa (27\%) followed by Staphylococcus aureus / Klebsiella species (17\%), while Proteus species [19], Bacillus species, Citrobacter species have the lowest percentage occurrence of $6 \%$ in POME from Umuahia, Abia State, Nigeria. Sinnapa showed that the variation of microorganism in POME sites could be attributed to the nature of the environment and that the population changes along disposal channel [18]. Another reason is the acclimatization and adaptation of these microorganisms' older POME deposits as suggested by Orji and Ihenetu $[9,16]$.

\section{Biochemical test results}

The biochemical test carried out for this microbiological analysis Pseudomonas spp, Seratia spp, Staphylococcus spp, and Bacillus spp. include catalase test, indole test, coagulase test, methyl red test, citrate test, motility test, urease test and sugar fermentation test. The biochemical identification of microorganisms gives us an idea of what these microorganisms are able to do, being possible the discrimination of different strains of the same species by specific biochemical profiles. Differences in concrete enzymatic activities tell us about the ecology, the physiology or the natural habitat of the microorganism.

(Table 3) shows the biochemical test carried out include gram staining, motility test, oxidase, catalase, citrate, coagulase, urease, indoleteste and sugar fermentation test. The fungal isolates include Aspergillus niger, Aspergillus flavus, Mucor species and Penicillium species. The fungal isolate was similar to fungal isolated in POME from Nguru reported by Verla [4].

Microscopic morphology and cultural characteristics of fungi isolates.

The result below shows the microscopic and cultural characteristics of the fungi isolates (Table 4).

\section{The physiochemical characteristics}

The result below shows the physiochemical characteristics of the samples of palm oil mill effluent analyzed which were labeled sample $\mathrm{A}, \mathrm{B}$ and $\mathrm{C}$, which include the $\mathrm{pH}$, electrical conductivity, temperature and moisture content.

From the result obtained from (Table 5), which shows the physiochemical characteristics which were calculated in line with their standard deviation for the samples obtained from the different palm oil mill effluents which were labeled sample A, B and C shows that the $\mathrm{pH}$ of the samples collected from different mill ranges from $3.98 \pm 0.03$ to

$4.22 \pm 0.02$. The electrical conductivity of the samples ranges from $291 \pm 0.8$ to $312 \pm 1.6$. The temperature of the samples ranges from $27.2 \pm 28.8 \pm 0.1$. Lastly, the moisture content of the samples ranges from $4.1 \pm 0.4$ to $6.0 \pm 0.1$. Same superscripts for values in the same column are not significantly different $(\mathrm{P}<0.05)$.

The results obtained for $\mathrm{pH}$ showed that the POME was strongly acidic. This observation is in contrast to results of [4], were a $\mathrm{pH}$ range of $6.8 \pm 0.22$ to $8.7 \pm 0.28$ showing weakly acidic to weakly alkaline reported for POME in Nguru, Aboh Mbaise, Eastern Nigeria. The receiving environment of high acidic POME will be adversely affected and thus may affect aquatic life or crops yield. $\mathrm{pH}$ is an important parameter that controls many chemical processes in environment matrix and therefore advisable that it undergoes some form of treatment or decomposition before discharge. When properly treated and packaged, it can be used by farmers both in rural and urban areas to improve soil fertility thereby increasing the agricultural productivity for global, national and regional food demands [19]. The treatment helps in avoiding the initial harsh effects of POME on soil meant for agriculture. There were no significant differences $(\mathrm{P}<0.05)$ between the different samples for $\mathrm{pH}$. The electrical conductivity measures the dissolved material in the POME, which relates to the ability of POME to conduct electrical current through it. The EC recorded in the present study are higher to values reported by [4] High EC indicates more dissolved materials in the studied samples. The dissolved materials include minerals inform of cations and anions and thus suggesting that POME could be useful as fertilizer at certain concentrations. Authors suggested that POME should be assessed carefully for potential mineral toxicity and thus it is important to always assess minerals in POME for toxicity before use [12,21].The EC follows the trend; $\mathrm{C}>\mathrm{B}>\mathrm{A}$ with only A found to be significantly different $(\mathrm{P}>0.05)$.

\section{Conclusion}

In this study, the population of microorganisms found in POME was enumerated. The POME had a high population of heterotrophic bacteria and fungi. The microbial isolates from study are the similar in all the processing mills with their occurrence following this order; Staphylococcus sp. (38\%) >Pseudomonas sp. (32\%) >Serratia sp and Bacillus sp (15\%). These microbes have direct applications in industrial process such as bioremediation and biodegradation of oily wastewater. The physiochemical characteristics of samples obtained from different mills labeled A,B and C shows similar characteristics, which confirm the non existence of effluent treatment of any form. 
Citation: Chukwuemeka IS, Ebere EC, Donald UA, Gerald UO. Biophysical Characterization of Palm Oil Mill Effluent from Adapalm, Imo State Nigeria. J Environ Stud. 2018;4(1): 4 .

ISSN: $2471-4879$

Table 5: Physiochemical characteristics of the sample.

\begin{tabular}{|c|c|c|c|c|}
\hline POME samples & $\mathbf{p H}$ & $\mathbf{E C} \boldsymbol{\mu S} / \mathbf{c m}^{-}$ & Temp ${ }^{\circ} \mathbf{C}$ & Moisture \\
\hline Sample A & $4.01 \pm 0.04^{\mathrm{a}}$ & $291 \pm 0.8^{\mathrm{a}}$ & $28.8 \pm 0.1^{\mathrm{a}}$ & $5.2 \pm 0.2^{\mathrm{a}}$ \\
\hline Sample B & $4.22 \pm 0.02^{\mathrm{a}}$ & $302 \pm 1.1^{\mathrm{b}}$ & $27.2 \pm 0.3^{\mathrm{b}}$ & $4.1 \pm 0.4^{\mathrm{b}}$ \\
\hline Sample C & $3.98 \pm 0.03^{\mathrm{a}}$ & $312 \pm 1.6^{\mathrm{b}}$ & $28.4 \pm 0.2^{\mathrm{a}}$ & $6.0 \pm 0.1^{\mathrm{c}}$ \\
\hline
\end{tabular}

Key: EC: Electrical Conductivity; Temp: Temperature

Same superscripts for values in the same column are not significantly different $(\mathrm{P}<0.05)$.

Some of the major obstacles to adoption of cleaner solutions in POME management in palm oil mills have been the total absence of sustainable technology and compelling economic arguments. There are reasons why POME has been treated and handled by millers as waste instead of resource POME has potential for use as medium for microalgae cultivation with significant saving in treatment costs. Due to variation in the composition of POME, the concentration that promotes the best biomass or product yield has to be predetermined in order to reduce the negative impact of the inhibitory components on the metabolism of cultures. Therefore, POME should be considered a valuable resource, and recovering it for other uses is much more preferable environmental alternative than the current treatment and disposal.

\section{References}

1. Akubor P, Ogu GI (2012) Quality attributes of fresh palm oil produced from selected communities around Anyigba, Kogi State, Nigeria. Niger J of Nutri Scien 33: 12-17.

2. Cheah $R$ (2003) Colour Removal from industrial effluent, a review of Available Technologies. Chem Engg World 32: 6-12.

3. Veneta Rao (2005) MPOA (Malaysian Palm Oil Association) and Sustainable Palm Oil, Communications/Public Forum KL/MP.

4. Verla AW, Addowei P, Verla EN (2014) Physiochemical and microbiologica characteristics of Palm Oil Mill Effluent (POME) in Nguru Aboh Mbaise Eastern Nigeria. Acta Chim Pharm Indica 4: 119-125.

5. Anyaoha KE, Sakrabani R, Patchigolla K, Mouazen AM (2018) Evaluating oil palm fresh fruit bunch processing in Niger. Waste Manag Res 36: 236-246.

6. Hemming ML (1997) Available solution to the palm oil effluent problem. In: international developments in palm oil processing and marketing. Earp DA, Newal IN (Eds). Rajio printers kuala lumpur 79-94.

7. Hartley CW (1988) Effluent disposal in, the Oil Palm (34 $4^{\text {th }}$ Eds). Longmans publications Ltd. London 720-723. Acta Chim Pharm Indica 4: 2014-2125.

8. Awotoye, OO, Dada AC, Arawomo GA (2016) Impact of palm oil processing effluent discharging on the quality of receiving soil and rivers in South Western Nigeria. J Appl Sci Res 7: 111-118.

9. Orji MU (2006) Microbiology and chemical studies on nigerian palm oil with particular refer to the effect of extraction methods on oil quality. Thesis Nnamdi Azikiwe Univ Awka 20: 1026-1031.

10. Ahmad AL, Ismail S, Bhatia S (2003) Water recycling from palm oil mill effluent (POME) using membrane technology. Desalination 157: 87-95.

11. Okwute OL, Isu NR (2007) Impact analysis of palm oil mill effluent on the aerobic bacterial density and ammonium oxidizers in a dumpsite in anyigba, Kogi State. African J Biotechnol 6: 116-119.

12. Bamikole MA, Ikhatua UJ (2009) Variety diversity effect on the chemical composition and dry matter degradation characteristics of residue and byproducts of oil palm fruits. Anim Sci J 80: 239-249.

13. Johnkennedy $U$, Owerri (2016) Imo palm plantation grounded, reptiles take over bushy compound. Agric Acce.

14. Enyoh CE, Ihionu EA, Verla AW, Ebosie NP (2017) Physicochemical Parameter of palm oil and soil from ihube community, Okigwe, Imo State, Niger. Int Let of Nat Sci 62: 35-49.

15. Chukwuemeka AN, Ngozi VE, Chuwkwuemeka IS, Wirnkor VA (2017) Physiochemical properties and selected metals in soil of Ohaji-Egbema, Imo state, Nigeria. Int J World News Nat Sci 10: 39-48.

16. Chukwuemeka IS, Chukwuemeka IF (2017) Physiochemical and microbiological analysis of canned and bottled fruit juices sold in owerri metropolis. Int J World Nat Sci 14: 97-105.

17. Ihenetu FC, Ihenetu SC, Ohalete CN, NjidekaNjoku-Obi T, Okereke BC (2017) Microorganism associated with cassava fermentation for abacha product sold in Owerri, Imo State. World News Nat Sci 12: 43-50.

18. Sinnapa S (1978) Treatment studies of palm oil mill waste effluent. Malaysia Agri J 261-272.

19. Eze VC, Owunna ND Avoaja DA (2013) Microbiological and physicochemical characteristics of soil receiving palm oil mill effluent in umuahia, Abia State, Nigeria. J Nat Scien Res 3: 163-169.

20. Bamikole MA, Ikhatua UJ (2009) Variety diversity effect on the chemical composition and dry matter degradation characteristics of residue and byproduct of oil palm fruits. Animal Sci J 80: 239-249.

21. Seephueak W, Ngampoogsai W, Chanjula P (2010) Effects of palm oil sludge in concentrate on nutri utilization and rumen ecology of Thai native cattle fed with hay. Songklanakarim J Sci Techn 33: 271-280. 